\title{
TELAAH TERHADAP BINDING AND LOOSING PRAYER: SEJAUH MANA OTORITAS ORANG PERCAYA DALAM PEPERANGAN ROHANI?
}

\author{
Murni Hermawaty Sitanggang
}

\begin{abstract}
ABSTRAK
Tulisan ini membahas problematika seputar doa mengikat dan melepaskan (binding and loosing prayer) atau yang juga populer dengan sebutan doa pelepasan. Bagi kalangan yang menganjurkannya, doa ini dianggap merupakan bagian penting dalam peperangan rohani yang harus dilakukan orang percaya setiap hari. Sedangkan bagi mereka yang menolaknya, doa ini lebih didasarkan pada pengalaman daripada penafsiran yang benar terhadap Alkitab. Tulisan ini akan membahas pro dan kontra tersebut kemudian menelaah ayat-ayat Alkitab yang biasanya dipakai untuk membenarkan praktik ini untuk kemudian menjawab pertanyaan utama: sejauh mana otoritas orang percaya dalam peperangan rohani.
\end{abstract}

Kata-kata kunci: peperangan rohani, otoritas, orang percaya, doa, pelepasan

\begin{abstract}
This article discusses the problem about binding and loosing prayer or deliverance prayer in its popular term. For the proponent, this concept, binding and loosing prayer is considered the important part in spiritual warfare that had to be practiced every day. Whereas the group who refuse assume this kind of prayer is arisen more from experience than the thorough biblical exegesis. This article will discuss the controversy about this binding and loose prayer and then examine the biblical verses that use to be basic for this prayer for answer the main question, to what extent the authority that believer has in spiritual warfare.
\end{abstract}

Keywords: spiritual warfare, authority, believer, prayer, deliverance 


\section{PENDAHULUAN}

Peperangan rohani adalah konsep yang tidak asing bagi orang percaya, khususnya di kalangan Pantekosta 114 dan Kharismatik. Alkitab menggariskannya dan orang percaya menghadapinya setiap hari. Meski Kristus telah menyelamatkan umat-Nya dari dosa, tetap saja selama masih berada di dalam dunia ini orang percaya ibarat berada di dalam "zona perang." Selain daging dan hawa nafsu, Iblis, yang bagaikan singa mengaum-aum mencari mangsa yang dapat ditelannya (1Ptr. 5:8), merupakan musuh yang harus dihadapi orang percaya dalam peperangan tersebut.

Menyadari betapa nyatanya peperangan rohani ini, kita sering mendengar doa yang diucapkan dalam mimbar yang isinya berupa seruan untuk menyerang dan mengusir Iblis, seperti: "segala kuasa kegelapan kami ikat dan hancurkan di dalam nama Tuhan Yesus Kristus." Doa semacam ini jamak diucapkan dalam pembukaan ibadah serta ketika hendak mendengarkan firman Tuhan di kalangan jemaat Pantekosta dan Kharismatik. Saking seringnya seperti menjadi tradisi sehingga jemaat menjadi terbiasa mendengar dan terbiasa mengucapkannya. Bahkan bukan hanya saat ibadah bersama saja, ada pengajaran berkembang yang menganjurkan agar doa mengikat dan melepaskan ini juga menjadi bagian dari doa pribadi orang percaya setiap hari. 115 Doa mengikat dan melepaskan yang sering juga disebut dengan doa pelepasan ini dianggap merupakan bagian dari strategi penting dalam peperangan rohani. Meski Tuhan Yesus telah mengalahkan Iblis dengan kematian-Nya di kayu salib, orang percaya tetap perlu melakukan doa ini untuk melawan Iblis dan mengklaim berkat-berkat yang dijanjikan Tuhan.

Akan tetapi, sebagian kalangan kemudian mempertanyakan keabsahan praktik dari doa "mengikat dan melepaskan" (binding and loosing) ini karena tidak didukung dengan dasar Alkitab yang kuat dan konkret. Umumnya kalangan pro dengan doa "mengikat dan melepaskan" ini menggunakan

114. Seringkali ada kebingungan membedakan istilah mana sebenarnya yang lebih baku, Pantekosta atau Pentakosta. Dalam hal ini penulis memilih mengikuti KBBI yang mencantumkan istilah Pantekosta daripada Pentakosta (kbbi.web.id).

115. Bern Zumpano, Spiritual Warfare Prayers (Miami, Florida: Harbor Light, 1999), 5. 
Matius 12:29; 16:18; 18:18 sebagai dasar. Ayat-ayat tersebut seringkali dikutip dalam praktik doa semacam ini, terutama Matius 16:19 yang menyatakan bahwa Tuhan memberikan "kunci" Kerajaan Allah kepada orang percaya sehingga apa yang mereka ikat di bumi akan terikat juga di surga dan apa yang mereka lepaskan di bumi juga akan dilepaskan di surga. Namun bagi kalangan yang kontra terhadap doa semacam ini menganggap tafsiran yang disampaikan oleh kalangan pro tersebut kurang tepat dan menuduh gerakan doa semacam ini menoleransi dan bahkan menganggap okultisme sebagai bagian dari kultur.116 Menurut pandangan mereka doa semacam ini telah membawa jemaat Tuhan ke arah yang salah dan mengurangi kadar sensitivitas umat akan kebenaran.117

Perdebatan ini kemudian menimbulkan pertanyaan: (a) tepatkah bagi kita untuk mempraktikkan doa "mengikat dan melepaskan" tersebut dalam setiap aktivitas rohani baik secara pribadi maupun dalam ibadah bersama, dan (b) sejauh mana sebenarnya otoritas orang percaya atas kuasa roh jahat. Oleh sebab itu, melalui artikel ini penulis hendak membahas problematika seputar isu tersebut dan kemudian mengajukan usulan strategi bagaimana yang sepatutnya dikembangkan oleh orang percaya dalam peperangan rohani. Isu ini perlu dibahas karena sebagai orangorang yang meyakini otoritas Alkitab dalam setiap aspek kehidupan, sudah seharusnyalah seluruh aspek kehidupan kita selaras dengan kebenaran firman Tuhan. Apa yang tertulis di dalam Alkitab sepatutnya meliputi setiap pemikiran, perkataan, dan tindakan dari orang percaya. Setiap praktik yang dilakukan oleh orang percaya haruslah berdasarkan penafsiran yang tepat.

\section{PROBLEMATIKA SEPUTAR DOA “MENGIKAT DAN MELEPASKAN”}

Sejarah dan Perkembangan 118

116. Growing Christian Ministries, "Binding Satan,"

https://www.growingchristians.org/devotions/binding-satan/ (diakses 29 Mei 2017).

117. Ibid.

118. Sebagian besar dari bagian ini diambil dari tulisan Paul L. King, "The Restoration of the Doctrine of Binding and Loosing" Alliance Academic Review 1997. http://www.kneillfoster.com/aar/1997/AAR1997-5.php. (diakses 6 Juni 2017). 
Mengikat setan merupakan bagian dari praktik eksorsis pada awal abad ketiga dan biasanya dilakukan sebelum seorang hendak dibaptis. Memang istilah "mengikat" (bind) dan "melepaskan" (loose) bukanlah istilah yang sering digunakan oleh bapa-bapa gereja mula-mula, namun konsep ini melekat dalam istilah "eksorsis" (pengusiran setan) yang lebih populer saat itu. Kedua hal ini, "mengikat" dan "melepaskan," dipandang sebagai satu kesatuan dengan proses eksorsisme.119

Bapa gereja Agustinus, menganggap Matius mengindikasikan bahwa Kristus masih sedang mengikat "orang kuat" tersebut. Dengan demikian ia berpendapat bahwa pengikatan Setan oleh Kristus merupakan sesuatu yang telah Yesus capai melalui invasi-Nya ke wilayah Setan di bumi, namun tetap saja harus ada tindakan yang bersifat meneruskan oleh gereja.120

Teolog lain yang sezaman dengan Agustinus, Chrysostom, meski tidak menampik otoritas mengikat dan melepaskan ada pada pendeta, ia berpendapat bahwa orang percaya pun memiliki otoritas untuk mengikat dan melepaskan. Di dalam khotbahnya, Chrysostom mengaitkan hal mengikat dan melepaskan tersebut bukan saja berkaitan dengan mengusir setan, melainkan juga dapat digunakan untuk berurusan dengan kekuatan jahat dan sakit-penyakit.

Dalam perkembangan selanjutnya, yakni di abad pertengahan, praktik mengikat dan melepaskan menjadi praktik resmi dan formal di dalam Gereja Katolik Roma. Pastor atau bishop menjadi pihak yang berwenang dalam melakukannya. Orang percaya tidak berhak lagi melakukan praktik ini. Namun kemudian ketika gereja memasuki masa Reformasi, terjadi kebangkitan pemikiran akan pentingnya peranan orang percaya dalam gereja. Akan tetapi, pada masa ini, gereja-gereja Reformasi memang cenderung mengesampingkan otoritas spiritual yang bersifat langsung dalam praktik ini.

119. Referensi yang paling signifikan mengenai "mengikat dan melepaskan" yang diasosiasikan dengan proses eksorsisme ini dapat dijumpai pada tulisan-tulisan intertestamental (atau yang disebut juga pseudepigrafa), seperti kitab Henokh, Kitab Yobel, dan yang paling jelas disinggung dalam Wasiat Duabelas Bapak Leluhur/Patriakh (Richard H. Hiers, “'Binding' and 'Loosing': The Matthean Authorization," Journal of Biblical Literature [Vol. 104, No. 2] [June 1985] p. 236).

120. Philip Schaff (ed.), NPNF1-08. St. Augustine: Exposition on the Book of Psalms. (Michigan: Grand Rapids, n.y.) 177. 
Memasuki abad ketujuhbelas dan kedelapanbelas, terjadi pembaharuan di dalam praktik mengikat dan melepaskan. Gerakan Pietis yang digagas Jacob Philip Spenner dan kaum teolog Lutheran Jerman saat itu, memberi perhatian khusus terhadap keimaman orang percaya. Akan tetapi, tetap saja otoritas orang percaya belum sepenuhnya diakui sampai pada masa pelayanan dan pengajaran dari Dorothea Trudel dan Johann Christoph Blumhardt di abad kesembilanbelas, yang menekankan otoritas orang percaya sebagai raja dan imam dari Tuhan.

Pembaharuan pemikiran akan otoritas orang percaya yang terjadi di akhir abad kesembilanbelas dan awal abad keduapuluh tersebut menimbulkan kesadaran akan natur dan otoritas dari praktik mengikat dan melepaskan. Salah seorang pengkhotbah terkenal pada abad kesembilanbelas, Henry Ward Beecher, ketika mengajar Matius 16:19 menyatakan bahwa setiap orang percaya yang berdoa memiliki kuasa dan otoritas untuk mengikat dan melepaskan, mengikat kebohongan dan ketidakadilan, serta melepaskan semua yang menderita tekanan kelaliman spiritual.

Andrew Murray dan Charles Spurgeon adalah beberapa pengkhotbah terkenal selanjutnya yang juga menegaskan konsep mengikat dan melepaskan. Murray mengasosiasikan hal mengikat dan melepaskan dengan praktik pengusiran setan oleh gereja.121 Sementara Spurgeon menyinggung konsep ini ketika berbicara tentang hak istimewa dan otoritas orang percaya dalam doa. Ia mencontohkan Elia yang berlatih untuk menggunakan kunci surga dengan doanya (Yak. 5:17).

Dalam perkembangannya, tahun 1897 dianggap sebagai tahun yang sangat penting bagi konsep mengikat dan melepaskan. Christoph Blumhardt, putra dari Johann Christoph Blumhardt, menyatakan dalam khotbahnya bahwa hanya orang yang menerima pewahyuan Allah yang dapat mengikat dan melepaskan. Orang itu dapat siapa saja dan tidak terbatas hanya kepada pendeta atau teolog saja. Di masa itu juga, A. B.

121. Dalam pengajarannya, Murray menegaskan bahwa doa orang percaya memiliki otoritas untuk membuat surga melepaskan berkat atau justru menahannya. Hal ini dimungkinkan karena pada dasarnya orang percaya adalah orang-orang yang terpanggil untuk menjadi penguasa (raja) dan imam atas dunia ini (Paul L. King, "John McMillan and the Authority of the Believer," http://pneumareview.com/john-macmillan-authorityof-the-believer. (Diakses 26 Agustus 2017). 
Simpson, pendiri dari Christian and Missionary Alliance, meneguhkan suatu prinsip yang jelas dari praktik mengikat dan melepaskan yang diberikan kepada gereja. John McMillan kemudian mengembangkan pengajaran Simpson tersebut dalam bukunya The Authority of Believer, buku yang kemudian berpengaruh besar dalam kegerakan Kharismatik karena menjadi acuan bagi tokoh-tokoh Kharismatik, seperti Kenneth Hagin, Michael Harper, Don Basham, d1l.122

Konsep mengikat dan melepaskan menjadi pengajaran standar di kalangan Kharismatik pada tahun 1970-an. Namun demikian ada juga kalangan non-Kharismatik yang mempopulerkan ajaran ini, di antaranya adalah Neil Anderson dan Larry Crabb. Mereka menyarankan agar proses mengikat dan melepaskan ini dilaksanakan berulang-ulang sampai orang tersebut mendapatkan kebebasan penuh dan kekuatan untuk mengalahkan si jahat.

Selain para teolog di atas, ada asumsi bahwa dua novel tentang peperangan rohani yang ditulis oleh Frank Peretti, yang berjudul This Present Darkness (1988) dan Piercing the Darkness (1989) juga berkontribusi secara tidak langsung dalam terbentuknya konsep doa peperangan rohani mengikat dan melepaskan ini.123 Dalam kedua novel tersebut, Peretti mampu untuk menggambarkan imajinasi yang kreatif tentang bagaimana roh-roh jahat dapat beroperasi untuk mempengaruhi apa yang terjadi dalam kehidupan sehari-hari di desa-desa, kota-kota, dan dunia pada skala besarnya. Tanpa bermaksud membangun konsep teologi secara khusus, Peretti telah memfasilitasi suatu sistematisasi kekuatan jahat di dunia melebihi apa yang sebenarnya Alkitab ajarkan.

Kemudian bersamaan dengan publikasi karya Peretti tersebut, C. Peter Wagner kemudian menjadi pemimpin dari pertumbuhan gerakan peperangan rohani yang populer dengan konsep power encounter. Teologi

122. Ibid.

123. PJ (Flip) Buys, "A Biblical and Reformed Perspective on Demonology," Christian Library: 4 www.christianstudylibrary.org. (diakses 22 Juni 2017). 
ini lalu berkembang menjadi gerakan yang cukup fenomenal, terutama dengan konsep DPRTS-nya (Doa Peperangan Rohani Tingkat Strategis).124

\section{Pandangan Pro}

Seperti yang telah disinggung sebelumnya di bagian awal, beberapa ayat yang sering digunakan oleh kalangan pro untuk mendukung pandangannya, antara lain: Matius $12: 29 ; 16: 19 ; 18: 18$. Ketiga ayat ini dijadikan acuan karena memang ketiganyalah yang paling jelas dalam memuat istilah "mengikat" dan "melepaskan." Matius 12:29 dan Matius 16:19 adalah yang paling populer dari ketiganya karena melukiskan dengan jelas situasi peperangan rohani yang dihadapi orang percaya, yakni peperangan melawan si jahat. Meski Lukas 11:21-22 merupakan ayat paralel dari ayat ini, kalangan pro jarang menggunakannya karena memang tidak ada istilah "mengikat" dan "melepaskan" dalam ayat tersebut.

Dalam pandangan kalangan yang pro, pada dasarnya setiap orang percaya telah menerima otoritas atau kuasa dari Tuhan untuk mengikat dan melepaskan sebagaimana ditegaskan di dalam Matius 12:29. Di dalam ayat tersebut Yesus menjelaskan bagaimana kita harus terlebih dahulu mengikat orang kuat sebelum dapat merampas harta bendanya. Demikian pula ketika orang percaya harus berhadapan dengan kuasa kegelapan di dalam kehidupan, ia harus terlebih dahulu menggunakan otoritas yang didapatinya ketika menjadi anak Tuhan, yaitu otoritas untuk mengikat kekuatan si jahat. Barulah sesudahnya ia dapat melepaskan atau meminta pemulihan dari Tuhan.125

Meski ada kesepakatan di kalangan teolog yang mendukung pandangan ini bahwa orang percaya pada dasarnya tak dapat dirasuki atau dikontrol sepenuhnya oleh Iblis, mereka meyakini orang percaya sesaleh apapun masih dapat dipengaruhi dan ditekan olehnya. Daimonizomai

124. Analisis yang mendalam tentang hal ini dapat dijumpai dalam tulisan Soerono, "Doa Peperangan Rohani Tingkat Strategis dan Biblical Warfare Worldview: Kawan atau Lawan?” Veritas (April 2008): 17-36.

125. "Prayer of Warfare-Binding and Loosing" https://truthinreality.com/2012/08/15/prayer-of-warfare/ (diakses 30 Mei 2017). 
merupakan kata kerja yang digunakan dalam menyatakan kasus kerasukan setan dalam Alkitab. Istilah tersebut kemudian menjadi dasar pemikiran akan pengaruh Iblis yang nyata dalam kehidupan orang percaya sehingga untuk menghadapinya, orang percaya perlu mengadakan doa pelepasan di mana praktek mengikat dan melepaskan merupakan bagian yang melekat di dalam doa tersebut. 126

Orang percaya dapat dan berhak mengikat dan melepaskan kuasa kegelapan karena pada dasarnya Yesus telah menganugerahkan kunci untuk memasuki Kerajaan Surga sebagaimana tertulis di dalam Matius 16:19.127 Ayat ini memiliki susunan yang tak jauh berbeda dengan Matius 18:18 sehingga seringkali dirangkai menjadi satu mengingat keduanya menggunakan ungkapan "apa yang kamu ikat di dunia ini akan terikat di sorga dan apa yang kamu lepaskan di dunia ini akan terlepas di sorga." Kata "mengikat" pada kedua ayat tersebut dalam bahasa Yunaninya memakai kata deo, yang berarti "mengikat tali, mengencangkan." Jadi, ketika kita mempraktikkan doa mengikat, itu berarti kita melarang atau mencegah sesuatu untuk terjadi dan membelenggunya agar tidak terjadi.

Sedangkan bahasa Yunani untuk kata "melepaskan" adalah lyo yang berarti "melepaskan seseorang (atau sesuatu) dari ikatan. Menerapkan konsep "melepaskan" dalam doa berarti mengidentifikasi hal-hal yang tidak sesuai dengan kehendak Allah kemudian mengikat hal-hal tersebut sambil melepaskan hal-hal baik untuk menggantikannya. Contoh: ketika kita mengenali adanya benih-benih kesombongan mulai masuk dalam hati kita, kita dapat berdoa seperti ini, "Saya mengikat kesombongan di dalam nama Tuhan Yesus dan melepaskan kerendahan hati." Jadi melepaskan yang

126. James K. Beilby dan Paul Rhodes Eddy, "Introduction” dalam Understanding Spiritual Warfare oleh James K. Beilby dan Paul Rhodes Eddy, eds., (Grand Rapids, Michigan: Baker Academic, 2012), 39.

127. Bern Zumpano, "The Prayer of Binding and Loosing" http://www.cryoutreach.com/prayer-ofbinding-and-loosing.html. (diakses 27 Agustus 2017). Kerajaan yang disinggung dalam ayat ini, menurut Zampano, mengacu kepada kerajaan Setan yang ada di bumi dan di surga atmosferik di atas bumi, tempat di mana roh-roh jahatnya mencoba untuk mencegah malaikat Tuhan untuk menjawab doa umat. Dengan melepaskan urapan dari kuasa Roh Kudus melalui iman, maka orang percaya akan dapat melepaskan diri dari belenggu apapun. 
dimaksud di sini adalah melepaskan sesuatu yang berlawanan dengan apa yang diikat. 128

Ketika orang percaya memanjatkan doa ini Allah akan mengirim malaikat-Nya untuk mengurus masalah yang mungkin akan atau yang sedang terjadi dalam kehidupan orang percaya yang memanjatkan doa tersebut atau dalam kehidupan orang yang menjadi sasaran doa.129 Doa ini dapat diibaratkan seperti borgol spiritual, yang dikenakan kepada roh jahat/kuasa kegelapan yang hendak atau sedang menganggu kehidupan orang percaya. Namun, borgol spiritual ini ternyata tidak bersifat permanen tetapi hanya sementara. 130 Karena sifatnya yang tidak permanen tersebut, Bern Zumpano berpendapat doa mengikat dan melepaskan adalah bagian dari pelayanan pelepasan yang harus dilakukan berulang-ulang dalam kehidupan orang percaya.131 Ketekunan dan iman adalah kuncinya. Pelepasan tetap harus dilakukan sampai terjadi perubahan yang sesuai firman Tuhan.132

Dalam pandangan kalangan pro, dunia ini ada di bawah pengaruh kuasa jahat, baik dalam bentuk roh maupun manusianya. Kuasa jahat tersebut menjadikan dunia ini kacau dan orang percaya terpanggil untuk menjadikannya baik kembali dengan melakukan doa pelepasan yang bersifat mengikat dan melepaskan kuasa si jahat.133 Doa ini dianggap sebagai bagian dari tanda-tanda heran dan kuasa manifestasi Roh Kudus yang melekat dalam kehidupan orang percaya.

128. "Binding and Loosing: The Keys to The Kingdom and Exercising Your Spiritual Authority" https://www.missionariesofprayer.org/2016/05/binding-and-loosing-the-keys-to-the-kingdom-and-exercisingyour-spiritual-authority/ (diakses 30 Mei 2017).

129. Ibid.

130. "Binding and Loosing - The Keys of the Kingdom" https://truthinreality.com/2013/07/12/bindingand-loosing-audio-on-omega-man-radio/ (diakses 30 Mei 2017).

131. Bern Zumpano, "The Prayer of Binding and Loosing” http://www.cryoutreach.com/prayer-ofbinding-and-loosing.html (diakses 30 Mei 2017).

132. Ketika orang percaya memanjatkan doa mengikat, imannya kepada Tuhan akan membuat surga melepaskan kuasa yang akan mengikat kuasa gelap yang sedang ia hadapi. Begitu juga ketika ia melepaskan sesuatu di bumi, itu sama artinya dengan mengizinkan dan mendeklarasikan sesuatu (yang dilepaskan tersebut) yang layak dan sah di bumi. Untuk itu, orang percaya harus memastikan apa yang diikat dan dilepaskan tersebut sesuai dengan firman Tuhan. Waktu yang paling tepat untuk melancarkan doa ini adalah di pagi hari sebelum memulai segala aktivitas. Jangka waktunya bisa berbeda-beda, tergantung situasi dan kondisi yang dihadapi. Ada yang membutuhkan satu atau dua sesi saja, namun ada juga yang memakan waktu hingga satu tahun (ibid.).

133 . "The Prayer of Binding and Loosing and Praying in Tongues" https://victorychristiancentre.co.nz/podcast/prayer-binding-and-loosing-and-praying-tongues (diakses 27 Agustus 2017). 


\section{Pandangan Kontra}

Pada umumnya mereka yang menolak praktik doa mengikat dan melepaskan ini mendasarkan pandangannya pada argumen bahwa tidak ada catatan di dalam Perjanjian Baru yang menyatakan Yesus dan muridmurid memang melakukan praktik ini. Selain itu, pengajaran ini juga dianggap membuat orang percaya "keasyikan" atau "terobsesi" dengan kuasa kegelapan dan terlalu mengagung-agungkan Setan. 134 George Hartwell berpandangan kegiatan ini membuat orang percaya lebih banyak memikirkan Setan atau roh apa yang perlu diikat daripada berpikir tentang Tuhan sehingga kemudian menimbulkan bahaya munculnya kecenderungan orang percaya untuk “menjadi seperti Tuhan.”135

Lebih lanjut Hartwell menegaskan pengajaran ini mendidik umat Tuhan menjadi beranggapan bahwa menghadapi kuasa kegelapan adalah tanggung jawabnya, bukan tanggung jawab Tuhan. Pengajaran ini gagal membedakan antara melakukan apa yang menjadi bagian orang percaya dengan apa yang seharusnya merupakan porsinya Tuhan, seakan-akan orang percaya memiliki otoritas yang penuh seperti Tuhan. Waktu yang seharusnya dapat digunakan untuk berdoa membangun keintiman dengan Tuhan, justru dihabiskan untuk mengurusi Setan dan kroni-kroninya. Hartwell bahkan dengan keras menyatakan hal ini membuat orang percaya seakan adalah "penyembah Setan." 136 Padahal Alkitab sendiri tidak pernah fokus terhadap roh-roh jahat. Bila kita menelusurinya dengan seksama maka kita akan mendapati bahwa Tuhan lebih menghendaki umat-Nya membangun keintiman dengan-Nya daripada yang lain-lain. Pengajaran semacam ini bukanlah pengajaran Kristen dan lebih mirip kepada pengajaran New Age yang fokusnya adalah memperkuat diri sendiri.

Pengajaran ini juga membuat Tuhan tampak "kurang berkuasa." Ketika orang-orang beralasan mereka mengikat dan melepaskan agar berkat dalam kehidupan mereka tidak terhalang, mereka membuat Tuhan

134. George Hartwell, "Spiritual Warfare Topic: Binding and Loosing" http://www.listeningprayer.com/spiritual\%20warfare/binding\%20and\%20loosing.html (diakses 30 Mei 2017).

135. Ibid. Lihat juga Ruth Marshall, "Destroying Arguments and Captivating Thoughts: Spiritual Warfare Prayer as Global Praxis" Journal of Religious and Political Practice (Vol. 2: No. 1) (p. 92-113) 100. 136. Hartwell, "Spiritual Warfare Topic." 
seakan tak dapat memberkati tanpa bantuan mereka. Mereka seperti hidup di dalam dunia di mana Allah seakan diborgol dan memohon supaya orang percaya membantu-Nya. 137

Tokoh lainnya, W. E. Nunally, juga dengan tegas menyatakan bahwa penggunaan istilah "mengikat dan melepaskan" versi modern ini justru tidak sesuai dengan penggunaannya dalam Perjanjian Baru. Bila ditelusuri, kata kerja "mengikat" dan "melepaskan" hanya muncul bersama dua kali (Mat. 16:19; 18:18). Karena kata Yunani yang sama untuk kata "melepaskan" (deo) juga muncul di dalam Matius 12:29, kalangan Pantekosta dan Kharismatik pada umumnya kemudian menyimpulkan ketiga ayat tersebut (Mat. 16:19; 18:18; 12:29) mengacu kepada otoritas orang percaya untuk "mengikat" roh jahat. Apa yang seharusnya menjadi konklusi sederhana dan mudah malah dipenuhi dengan kesulitan-kesulitan yang sifatnya kontekstual, teologis, dan praktis.138

\section{Penyebab Perdebatan}

Bila ditelusuri lebih jauh, terjadinya perdebatan antara kalangan pro dan kontra mengenai doa ini disebabkan karena adanya perbedaan pemahaman akan karya Roh Kudus, apakah masih terus berlanjut dalam kehidupan gereja atau orang percaya saat ini (continuation atau disebut juga non-cessationism) 139 ataukah sudah berhenti (dis-continuation atau

137 . Denver Cheddie, "Are We Supposed to 'Bind and Loose'?" http://www.bibleissues.org/bindloose.html (diakses 30 Mei 2017).

138. W.E. Nunnally, "Binding and Loosing: A Biblical Perspective on a Popular Modern Practice" http://enrichmentjournal.ag.org/200901/200901_112_theo_enrichment.cfm (diakses 29 Mei 2017).

139. Kaum non-cessationist atau yang disebut juga continuity ini mempercayai bahwa: 1) Tuhan masih berbicara kepada umat-Nya saat ini selain melalui Alkitab (namun tetap sesuai dengan isi firman Tuhan dan tetap tunduk pada otoritas Alkitab); 2) Tuhan masih mengerjakan mukjizat dan tanda-tanda heran; 3) semua karunia Roh Kudus masih beroperasi hingga kini (seperti bahasa lidah, nubuat); 4) kelima jawatan yang disebut dalam Efesus 4:11-12 masih tetap berfungsi sampai sekarang ("The Case Against Cessationism," http://mysouthland.com/Resources/Theology/The\%20Case\%20against\%20Cessationism.pdf. [diakses 26 Agustus 2017]). Sebenarnya isu utama yang menjadi bahan perdebatan antara kaum non-cessationism (continuity) dengan cessationism (discontinuity) bukanlah soal apakah Allah masih berkuasa dalam melakukan mukjizat pada masa kini melainkan soal apakah Allah masih mengerjakan mukjizat tersebut lewat individual sebagai utusan-Nya. Pada dasarnya, isu tentang apakah karunia-karunia Roh masih beroperasi hingga sekarang atau tidak, tidaklah berkenaan dengan soal kuasa Tuhan. baik kaum Cessationist maupun non-Cessationist sama-sama meyakini Allah masih tetap berkuasa hingga sekarang (Daniel B. Wallace, "Two Views on the 'Sign Gifts': Continuity Vs. Discontinuity” https://bible.org/article/two-views-sign-gifts-continuity-vs-discontinuity. [diakses 26 Agustus 2017]). 
cessationism).140 Pada umumnya, bila tidak dapat dikatakan semuanya, kalangan pro merupakan penganut paham continuity/continuation/noncessationism sementara kalangan kontra adalah mereka yang menganut paham discontinuity/discontinuation/cessationis.

Mengikat dan melepaskan kuasa si jahat, dalam pemahaman kalangan pro (noncessationist), diyakini merupakan bagian dari tanda-tanda heran yang akan menyertai orang percaya dan juga sebagai bagian dari karunia Roh Kudus, yakni karunia membedakan roh yang disebutkan dalam 1 Korintus 12. Menurut mereka karunia tersebut tersedia dan vital bagi setiap orang percaya untuk dapat menang dalam peperangan rohani. 141 Hal ini tentu saja ditentang oleh kalangan kontra (cessationist), yang meyakini bahwa tanda-tanda heran tersebut sudah berhenti dan tidak beroperasi lagi saat ini (cessationist). Ini bukan berarti mereka meyakini Tuhan tidak melakukan mukjizat-Nya lagi di masa kini, melainkan mereka meyakini bahwa pada dasarnya tidak semua karunia dan tanda-tanda heran yang terjadi di zaman gereja mula-mula juga berlanjut hingga kini. Hanya jawatan penginjil, guru, dan gembala serta karunia-karunia yang bersifat melayani, yang bersifat administratif, menasihati dan mendorong, memberi serta menunjukkan kemurahan sebagaimana tertulis di dalam Roma 12:7-8, yang mereka anggap bersifat permanen (masih berlanjut hingga kini). 142 Perbedaan pandangan inilah yang kemudian

140. Kalangan cessationism berpendapat: 1) mukjizat kesembuhan dan tanda-tanda heran hanya dapat dilakukan oleh para rasul sesuai kesaksian dari kitab Kisah Para Rasul; 2) bahasa lidah sudah berhenti karena kanonisasi Alkitab sudah selesai dan Injil telah disampaikan dalam berbagai bahasa di dunia sehingga karunia ini tak diperlukan lagi; 3) karunia bahasa lidah yang alkitabiah adalah benar-benar merupakan bahasa dan bukan semacam kata-kata yang tidak jelas artinya sebagaimana yang terjadi di masa kini; 4) Perjanjian Baru tidak pernah menyebutkan instruksi untuk mengangkat rasul, nabi, penyembuh, dan sejenisnya (kelima jawatan yang disebut dalam Efesus 4:11-12 praktis hanya menyisakan gembala, penginjil, dan guru di masa kini); 5) pewahyuan telah selesai sehingga nubuat tidak diperlukan lagi (diyakini telah berhenti) (Peter Masters, "Cessationism-Proving Charismatic Gifts have Ceased" http://www.metropolitantabernacle.org/ChristianArticle/Cessationism-Proving-Charismatic-Gifts-have-Ceased-Sword-and-Trowel-Magazine\# diakses 26 Agustus 2017).

141 . Don Ibbitson, "How to Develop the Gift of Discerning Spirits," https://aandbcounseling.com/develop-gift-of-discerning-spirits/ (diakses 26 Agustus 2017). Untuk dapat memperoleh karunia tersebut, orang percaya hanya perlu memintanya dan kemudian mempraktikkannya dengan mendeklarasikan doa mengikat dan melepaskan ketika dibutuhkan. Menurut Ibbitson, ada kemungkinan terjadi orang percaya keliru dalam menerapkannya, tetapi itu tidak menjadi masalah karena merupakan bagian dari latihan yang mendewasakan. $172-175$.

142. James Stitzinger, "Spiritual Gifts: Definitions and Kinds” TMSJ (14/2) (Fall 2003) (p. 143-176) 
menimbulkan berbagai perdebatan teologis yang sulit didamaikan, salah satunya tentang konsep doa mengikat dan melepaskan ini.

\section{TINJAUAN ALKITAB TERHADAP AYAT-AYAT YANG DIGUNAKAN}

Matius 12:29

Matius 12:29: "Atau bagaimanakah orang dapat memasuki rumah seorang yang kuat dan merampas harta bendanya apabila tidak diikatnya dahulu orang kuat itu? Sesudah diikatnya barulah dapat ia merampok rumah itu."

Pada umumnya, baik kalangan pro maupun kontra sepakat bahwa "orang kuat" yang dimaksud di dalam ayat ini adalah mengacu kepada Setan. Dari kalangan pro, Paula White,143 misalnya, berargumen "seorang yang kuat" (strong man-NIV) dalam ayat ini mengacu pada pribadi Setan yang bertanggung jawab atas rumah tersebut. Setan berusaha membangun entitas sebagai orang kuat untuk meninggikan dirinya dalam menentang rencana dan kehendak Tuhan. Pada hakikatnya, Setan selalu berusaha untuk beroperasi di bawah kuasa kegelapan. Oleh sebab itu, sepanjang kubu pertahanannya tetap tersembunyi, ia tetap aman. Namun begitu ia teridentifikasi maka separuh kemenangan telah ada di tangan orang percaya.144 Kemudian ketika orang percaya melancarkan doa mengikat, maka kemenangan tersebut menjadi mutlak.

Berbeda dengan White dan kalangan pro lainnya, Nunnally, meski tidak menampik bahwa "orang kuat" tersebut adalah Setan, berpandangan ayat ini tidaklah berbicara tentang eksorsisme. Injil memang mencatat bagaimana Yesus banyak kali berkonfrontasi dengan roh-roh jahat, namun tak ada catatan yang menyebut Ia "mengikat" roh jahat sebelum mengusirnya keluar. Lagipula, praktik mengikat roh jahat juga tak dijumpai di dalam kitab Kisah Para Rasul, surat-surat rasul maupun di

143. Salah seorang penganjur dari doa mengikat dan melepaskan, yang juga adalah pengkhotbah terkenal di Amerika Serikat. Ia merupakan wanita pertama yang dipercaya untuk berdoa saat penahbisan presiden, tepatnya saat pelantikan Presidan AS Donald Trump pada tanggal 20 Januari 2017 ("Paula White," https://en.wikipedia.org/wiki/Paula White [diakses 7 Juni 2017]).

144. "Prayer: Binding The Strongman," https://paulawhite.org/binding-the-strongman-2016/ (diakses 30 Mei 2017). 
kitab Wahyu. 145 Pada umumnya, Yesus dan pengikut-Nya memakai formula yang sama ketika melakukan hal yang sama, yakni langsung memerintahkan roh jahat untuk keluar.

Bila melihat konteks ayat tersebut, penulis lebih menyetujui pendapat Nunnally yang menyatakan Matius 12:29 (dan paralelnya Mrk. 3:27) lebih tepat diterjemahkan sebagai analogi (teknik ilustrasi yang sering Yesus terapkan di keempat Injil) daripada suatu perintah.146 Setan bukanlah manusia atau orang, namun ia mirip dengan orang kuat yang harus ditaklukkan lebih dulu sebelum pencuri dapat merampok rumahnya. Itu sebabnya Setan harus dilucuti terlebih dahulu sebelum kedatangan Kerajaan Allah (Mat. 12:28).

Bila kita membaca ayat-ayat sebelumnya (ay. 26-29), maka kita akan mendapati bagaimana Yesus pertama-tama menunjukkan betapa tidak logisnya pernyataan orang Farisi dengan menjelaskan bahwa jika Setan mengusir Setan, maka kerajaannya tidak mungkin bertahan. Yesus kemudian menandaskan bahwa Ia mengusir Setan dengan kuasa Roh Kudus karena Ia adalah orang kuat. Yesus menggunakan metafora di ayat 29 untuk menjelaskan misi-Nya lebih lanjut. Tidak seorang pun dapat memasuki rumah seseorang dan menjarahnya jika ia tidak mengalahkan orang kuat di dalam rumah tersebut terlebih dahulu. Oleh sebab itu, jika Yesus bukanlah Mesias, yang lebih kuat dari Setan, bagaimana Ia dapat mengusirnya? 147

Lukas 11:21-22, yang merupakan ayat paralel dengan Matius 12:29, bahkan tidak memakai istilah "mengikat" di dalam ayat-ayat tersebut melainkan memakai ungkapan "menyerang dan mengalahkannya, . . . merampas perlengkapan senjata, yang diandalkannya, dan akan membagibagikan rampasannya." Bila memperbandingkan istilah yang digunakan oleh Lukas dengan yang digunakan oleh Matius, kita dapat berasumsi

145. Nunnally, "Binding and Loosing".

146. Ibid.

147. Gambaran yang dilukiskan Matius dalam ayat ini juga mirip dengan Efesus 4:7-10 meski tidak ada musuh yang secara jelas disebutkan di dalam ayat-ayat tersebut. Yang jelas adalah Yesus telah menang melawan Setan. Oleh sebab itu, proses penyembuhan yang dilakukan Yesus di dalam Matius 12:22 dapat diterjemahkan sebagai perang telah dimenangkan dan Kerajaan Surga sedang datang ("Matthew 12" https://bible.org/netbible/ [diakses 24 Juni 2017]). 
bahwa kata "mengikat" yang digunakan oleh Matius pada dasarnya digunakan secara insidental untuk menunjukkan bagaimana orang kuat tersebut ditaklukkan.148 Apakah orang kuat tersebut ditaklukkan dengan diikat, diserang, dirampas, dilucuti, dan lain sebagainya, sebenarnya bukanlah hal yang penting. Oleh sebab itu, kurang tepat rasanya ketika istilah "mengikat" dan "melepaskan" tersebut kemudian ditafsirkan sebagai otoritas untuk menengking sifat-sifat buruk (kesombongan, minder, kemalasan, dst.), sakit-penyakit, gangguan-gangguan lain, seperti yang diyakini oleh mereka yang pro terhadap doa mengikat dan melepaskan.

Fakta yang lebih penting yang ditekankan oleh ayat ini (lebih penting dari soal mengikat dan melepaskan) adalah orang kuat tersebut hanya dapat dikalahkan oleh orang yang lebih kuat. Dengan demikian, kita dapat menarik garis tegas bahwa orang yang lebih kuat tersebut adalah Yesus karena memang Ia adalah Allah, yang dalam inkarnasi dan karya penebusan-Nya, telah mengalahkan kuasa kegelapan dengan kematian-Nya di kayu salib.

Rampasan atau hasil rampokan yang dibahas baik di dalam Matius 12:29 maupun Lukas 11:21-22 adalah berbicara tentang orang-orang yang hidup tertindas di bawah kuasa kegelapan karena dosa, orang-orang yang belum diselamatkan. Kedatangan Yesus yang menaklukkan Setan membebaskan kita, orang-orang yang sebelumnya terbelenggu tersebut. Hal ini menandaskan kebenaran hakiki bahwa tak seorang pun dapat membebaskan atau menyelamatkan dirinya dari belenggu Iblis. Hanya Yesus dengan karya penebusan-Nya yang sanggup melakukan hal itu.149

Jadi, pada dasarnya ayat ini berbicara tentang kuasa Yesus yang mengalahkan kuasa kegelapan. Dengan kemenangan-Nya atas Iblis, Yesus membebaskan orang percaya dari belenggu dosa. Meski ayat ini memang memakai frasa "mengikat orang kuat," fokus utamanya adalah kekalahan orang kuat tersebut adalah karena ia bertemu dengan orang yang lebih kuat, bukan soal metode mengikatnya.

148. "Binding and Loosing: Introduction" http://www.bindingandloosing.com/ (diakses 30 Mei 2017).

149. Lihat John Calvin, Commentary on Matthew, Mark, Luke - Volume 2 (Michigan: Grand Rapids: n.y.) 59-60. Christian Classical Ethereal Library Commentary Ebook. 
Matius 16:19

“Kepadamu akan kuberikan kunci Kerajaan Sorga. Apa yang kauikat di dunia ini akan terikat di surga dan apa yang kaulepaskan di dunia ini akan terlepas di sorga."

Dalam tafsirannya, Adam Clarke berpendapat bahwa yang dimaksud oleh "Kerajaan Sorga" dalam ayat ini adalah berbicara tentang gereja Tuhan yang sejati, sedangkan kata "kunci" di sini mengacu kepada otoritas untuk memasukkan atau mencegah sesuatu yang tak layak untuk memasukinya. 150 Dalam tradisinya, ketika orang Yahudi hendak menahbiskan seseorang sebagai ahli kitab Taurat, mereka meletakkan kunci tempat penyimpanan Kitab Suci di Bait Allah ke dalam tangan orang tersebut. Hal ini menandakan mereka memberikan otoritas kepada orang tersebut untuk mengajar dan menjelaskan Kitab Suci kepada umat Tuhan. Hampir senada dengan Clarke, John Gill juga menafsirkan kata "kunci" yang dimaksud dalam ayat ini sebagai kemampuan untuk menjelaskan kebenaran Injil dan merupakan misi dan tugas yang diberikan Kristus. 151 Tugas itu dikatakan diberikan kepada Petrus secara khusus mengacu kepada bagaimana ia kemudian menjadi orang pertama yang mengabarkan Injil kepada orang Yahudi di dalam Kisah Para Rasul 2. Ia dan rasul-rasul lainnya kemudian bertanggung jawab menyebarluaskan Injil tersebut kepada bangsa-bangsa lain.

"Apa yang kauikat di dunia ini"- orang Yahudi acapkali mempertimbangkan bahwa apa yang telah diselesaikan di bumi, bila menurut kehendak Allah, maka pada saat yang sama juga terselesaikan di surga. Oleh karenanya, mereka biasa berkata bahwa ketika imam pada hari penebusan, mempersembahkan dua kambing di bumi, ia juga mempersembahkannya di surga. Ketika salah seekor kambing dilepaskan di bumi, kambing yang lainnya dilepaskan di surga, ketika imam melempar undian di bumi, ia juga mengundi di surga. Contoh yang paling jelas di dalam Alkitab adalah di dalam Imamat 13:3 dan 13:23, ketika imam

150 . Adam Clarke, "Matthew 16:19" https://www.studylight.org/commentary/matthew/16-19.html (diakses 31 Mei 2017). Lihat juga Matthew Henry, Commentary on the Whole Bible Volume 5 (Michigan: Grand Rapids: n.y.) 416. Christian Classical Ethereal Library Commentary Ebook.

151. John Gill, "Matthew 16:19" http://www.biblestudytools.com/commentaries/gills-exposition-of-thebible/matthew-16-19.html (diakses 31 Mei 2017). 
memeriksa apakah seseorang terkena kusta atau tidak. Bila menurut pengamatannya orang tersebut mengalami tanda-tanda kena kusta maka ia akan menyatakan orang tersebut najis. Sebaliknya jika ternyata orang tersebut menurut pengamatannya sudah sembuh atau tahir, maka imam tersebut akan mendeklarasikannya tahir.

Menurut Clarke, murid-murid Tuhan setelah mendapatkan kunci tersebut (pengetahuan sejati tentang Kerajaan Surga), akan mampu membedakan antara yang suci dan yang najis, menyatakan pertimbangan yang sempurna berdasarkan kehendak Tuhan.152 Jadi, pada dasarnya ayat ini sebenarnya berbicara tentang membangun gereja. Kunci yang Yesus berikan adalah kunci untuk membuka Kerajaan Sorga, bukan untuk mengunci atau mengikat kuasa kegelapan.153 Arah dari perkataan Yesus dalam ayat ini adalah Petrus dan rasul-rasul lainnya harus diperlengkapi dengan kuasa-Nya sehingga dengan arahan Roh Kudus, apa yang mereka ikat atau yang mereka nyatakan terlarang dan tidak benar, jadilah demikian dan apa yang mereka lepaskan, yakni yang mereka nyatakan sah dan dapat digunakan, jadilah demikian. Contohnya: mereka mengikat atau menyatakan terlarang atau tidak sah praktik sunat, yang sebelum dihapuskan oleh kematian Kristus merupakan tradisi dan kewajiban bagi orang Yahudi (Gal. 5:1, 3, 6). Rasul-rasul juga melarang peringatan harihari khusus, seperti bulan baru dan tahun sabat, yang sebelumnya dilestarikan oleh jemaat Yahudi (Gal. 4:9, 10; Kol. 2:16, 17). Sementara itu, hal yang mereka nyatakan sah dan dapat dilakukan, antara lain: percakapan religius antara orang Yahudi dengan non-Yahudi, meski sebelumnya orang Yahudi tidak diperkenankan berhubungan dengan orang bukan Yahudi. Setelah penebusan Kristus dan Amanat Agung, baik orang Yahudi maupun bukan Yahudi memiliki kedudukan yang sama di hadapan Tuhan (Kis. 10:28; 11:2-3, 18; Gal. 3:28).154

Harus diakui ada kemiripan antara konstruksi gramatika ayat ini dengan Matius 18:18. Yang kemudian membedakan adalah pasal 16 mengacu kepada otoritas kepemimpinan gereja untuk melarang atau 
mengizinkan pengajaran yang berlaku di dalam komunitas perjanjian Tuhan, sedangkan pasal 18 berbicara soal otoritas pemimpin untuk melarang atau mengizinkan keberlangsungan keanggotaan jemaat dalam komunitas perjanjian. Fakta bahwa kata kerja "mengikat" (bind) dan "melepaskan" (loose) muncul di kedua pasal ini dan tidak ditemukan di bagian Alkitab lainnya, menunjukkan konteks yang terdapat di antara keduanya saling terkait.

Menurut International Standard Version, ayat ini seharusnya diterjemahkan sebagai berikut: "I will give you the keys to the kingdom of heaven. Whatever you prohibit on earth will have been prohibited in heaven, and whatever you permit on earth will have been permitted in heaven." Jadi, dapat kita lihat bahwa dalam terjemahan ini tidak ada kata binding dan loosing. ISV lebih memilih menggunakan kata prohibit dan permit. Ini tidak berarti bahwa pemimpin gereja memutuskan suatu masalah lalu mengikat surga dengan keputusan mereka, tetapi keputusan mereka sudah terlebih dahulu selaras dengan kehendak Tuhan. Jadi, sebelum mereka mengambil keputusan, pemimpin gereja harus bertanya terlebih dahulu kepada Tuhan dan setelah mereka mendapat keyakinan akan keputusan yang akan diambil, maka keputusan tersebut berarti sah di mata Tuhan dan di hadapan manusia.

Ayat ini menegaskan Tuhan akan mengesahkan keputusan yang diambil para pemimpin gereja dengan persetujuan-Nya. Tentu saja ini bukan berarti Kristus wajib menyetujui semua aturan maupun kecaman yang dikeluarkan gereja, benar maupun salah; melainkan hanya hal-hal yang bersifat sewajarnya saja. Dengan kata lain, perkataan Injil yang keluar dari mulut pelayan yang setia haruslah dipandang sebagai perkataan Tuhan, bukan sebagai kata-kata manusia belaka, dan diterima dengan sepatutnya. 155

Dengan memahami tafsiran yang sebenarnya dari ayat tersebut, rasanya sangat jauh bila kemudian ayat ini dijadikan acuan dalam praktik doa mengikat dan melepaskan. Konteks dari ayat ini bukanlah peperangan rohani dan inti sesungguhnya berbicara tentang otoritas para rasul saat itu

155. Henry, Commentary on the Whole Bible Volume 5. 
dan para pemimpin gereja di masa kini untuk menetapkan ajaran (dogma) dan aturan yang sesuai dengan kebenaran firman Tuhan.

\section{Matius 18:18}

"Aku berkata kepada: Sesungguhnya apa yang kamu ikat di dunia ini akan terikat di sorga dan apa yang kamu lepaskan di dunia ini akan terlepas di sorga."

Di dalam ayat ini, kita mendapati Yesus mengulangi apa yang sebelumnya telah ia nyatakan di dalam Matius 16:19, tetapi dengan pengartian atau arah yang berbeda. Bila di Matius 16:19 Ia bermaksud mempertahankan otoritas para rasul dalam doktrin atau pengajaran, maka di dalam ayat ini Ia mengacu kepada disiplin gereja, yang merupakan bagian dari doktrin. 156 Jika di Matius 16:19 Yesus mendeklarasikan bahwa mengkhotbahkan Injil tidaklah tanpa efek, di sini Ia mengingatkan bahwa bagi mereka yang memandang remeh peringatan Tuhan akan selalu ada akibatnya.

Untuk menghasilkan tafsiran yang benar, kita sepatutnya memperhatikan konteks literal dekat dari ayat ini. Kita tidak dapat memperoleh pengertian yang menyeluruh bila mengesampingkan ayat-ayat sebelumnya. Oleh karena itu, ada beberapa elemen yang perlu diperhatikan ketika membaca ayat 15-17, antara lain: "saudara yang berbuat dosa" (ay. 15), "tegorlah ia” (ay. 15), "saksi" (ay. 16), "jemaat” (ay. 17), dan ekskomunikasi ("pandanglah dia sebagai seorang yang tidak mengenal Allah atau seorang pemungut cukai-ay.17). Adanya elemenelemen tersebut dengan jelas menyatakan bahwa ayat 18, yang merupakan kesimpulan ayat-ayat sebelumnya, bukanlah berbicara mengenai pengusiran setan (eksorsime) melainkan tentang ekskomunikasi. Di dalam konteks inilah, Matius memakai kata "mengikat dan melepaskan." Pemimpin gereja menjadi pihak yang bertanggung jawab untuk menentukan siapa yang dapat tetap tinggal di dalam komunitas perjanjian baru dan dengan syarat bagaimana. 157

156. Calvin, Commentary on Matthew, Mark, Luke - Volume 2.

157. Nunnally, "Binding and Loosing." 
Dua ayat sesudahnya (ay. 19 dan 20) juga semakin menguatkan fakta bahwa natur perikop tersebut bukanlah berbicara tentang eksorsisme melainkan permufakatan dalam melaksanakan disiplin gereja. Frasa "dua atau tiga orang" yang ditulis di dalam ayat 20 bukanlah angka yang acak. Jumlah tersebut mengacu kepada "saksi" di dalam ayat 17 . Dalam memutuskan perkara pengadilan, biasanya hakim akan memanggil saksi sebelum menetapkan kesalahan seseorang (lih. U1. 17:6, 7; 19:15-21; 1Tim. 5:19) sebelum menjatuhkan putusan.

Jika gereja mengeluarkan kecaman atau hukuman yang seturut dengan ketentuan yang digariskan oleh-Nya, maka penghakiman Kristus akan mengikuti kecaman gereja karena Ia tak akan membiarkan peraturanNya diinjak-injak. Matthew Henry bahkan dengan tegas menyatakan bahwa mereka yang mencemooh aturan tersebut, mereka harus mengetahui bahwa kesalahan mereka sudah dikonfirmasi di surga dan merupakan kesia-siaan bagi mereka untuk bersikeras untuk membela diri sebab hukuman sudah dijatuhkan bagi mereka. 158 Akan tetapi, hukuman tersebut tidaklah menutup pintu bagi pertobatan yang bersangkutan. Jika saudara yang telah diputuskan bersalah itu kemudian bertobat, maka ia berhak masuk kembali ke dalam komunitas gereja Tuhan.

Dengan demikian, dapat kita simpulkan bahwa sama seperti Matius 16:19, Matius 18:18 ini juga berbicara tentang otoritas para rasul saat itu dan para pemimpin gereja saat ini dalam mengambil langkah tegas yang perlu dilakukan dalam menegakkan disiplin gereja. Meski kita hidup di masa kasih karunia, orang percaya tetap perlu menghormati aturan yang ditetapkan oleh para pemimpin gereja untuk kebaikan bersama. Akan tetapi, dalam menetapkan peraturan dan disiplin gereja, pemimpin rohani tersebut haruslah memastikan semuanya berlangsung sesuai dengan kebenaran firman Tuhan. Jadi, ayat ini sama sekali bukan berbicara tentang otoritas orang percaya dalam peperangan rohani.

\section{Simpulan}

158. Henry, Commentary on the Whole Bible Volume 5. 
Setelah membahas ketiga ayat yang sering menjadi acuan dalam perdebatan tentang binding and loosing prayer tersebut, penulis menyimpulkan bahwa praktik doa "mengikat dan melepaskan" tidak didukung oleh penafsiran yang benar terhadap Matius 12:19; 16:19; 18:18. Matius 12:19 berbicara tentang kekuatan Tuhan yang menaklukkan Iblis. Sementara Matius 16:19 dan 18:18 berbicara tentang otoritas yang Tuhan berikan kepada pemimpin gereja untuk menetapkan ajaran dan memberlakukan sanksi bila diperlukan. Selain itu, tidak ada contoh di dalam Perjanjian Baru yang mencatat Yesus dan rasul-rasul menganjurkan dan menggunakan doa semacam itu. Memaksakan ayat-ayat tersebut sebagai dasar untuk melakukan doa mengikat dan melepaskan atau doa pelepasan pribadi setiap hari sama saja dengan mengabaikan aturan penting yang seharusnya dijalankan dalam hermeneutik, yakni Sacra Scriptura sui ipsuis interpres. Ketika kita menggali tujuan dan makna ayat Alkitab, kita haruslah memperhatikan bagian di mana ayat tersebut terdapat secara keseluruhan dan suatu doktrin sepatutnya diformulasikan melalui perbandingan berbagai bagian yang berbicara tentang hal yang sama. Doa ini memberi orang percaya otoritas yang melebihi apa yang sebenarnya digariskan oleh Alkitab.

\section{OTORITAS ORANG PERCAYA ATAS SETAN DALAM PEPERANGAN ROHANI}

Sebelum menjawab pertanyaan selanjutnya, sejauh mana sebenarnya otoritas orang percaya di dalam peperangan rohani, kita perlu menyadari bahwa peperangan rohani merupakan fakta yang tak dapat diabaikan dalam kehidupan orang percaya. Kita tidak dapat menampik fakta bahwa kuasa kegelapan berada di balik kemerosotan moral yang terjadi di masa modern ini. Kecanduan obat-obatan, hedonisme, perkembangan industri pornografi yang pesat, sikap meremehkan kekudusan hidup manusia, sekularisme, merupakan sekian banyak cara yang dilakukan Iblis dan kroni-kroninya untuk menjauhkan manusia dari Tuhan.159

159. Buys, “A Biblical and Reformed Perspective on Demonology,” P. 2. 
Berbicara soal peperangan rohani, ada beberapa fakta penting yang perlu kita garis bawahi: pertama, orang percaya tidaklah imun terhadap serangan Iblis. 160 Selain serangan terhadap pikiran, serangan tersebut dapat terwujud melalui ajaran-ajaran palsu (1Tim. 4:1; 1Yoh. 4:1-4), mukjizat-mukjizat palsu (2Tes. 2:7-11; Why. 16:4). Setan juga dapat menyerang fisik, seperti yang dialami oleh Paulus yang digocoh oleh Iblis (2Kor. 12:7). Meski Alkitab tidak memberi gambaran yang jelas seperti apa Iblis menggocoh Paulus, tetapi kita mengetahui dengan pasti bahwa "utusan Iblis" yang melakukannya dan Paulus tidak dapat mengusirnya dengan doa. Tentu saja itu bukan karena kuasa Iblis yang terlampau besar, melainkan lebih kepada Tuhan mengizinkan hal tersebut terjadi kepada Paulus untuk mengajarnya bergantung sepenuhnya kepada Tuhan.

Orang percaya juga perlu menyadari bahwa Iblis adalah musuh yang kuat dan berbahaya. Meski tidak terucapkan melalui mulut, banyak anak Tuhan yang menunjukkan sikap meremehkan Iblis dengan gaya hidupnya.161 Contoh nyata hal ini adalah orang tua yang membebaskan anaknya melihat atau menonton apa saja dan pergi ke mana saja. Meski Iblis memang tak dapat lagi berbuat semaunya terhadap anak Tuhan, kita tetap harus berwaspada terhadap tipu-muslihatnya. Selama masih terbuat dari darah dan daging, orang percaya masih dapat jatuh ke dalam dosa.

Kedua, pada dasarnya sebagai orang percaya, kita memang memiliki otoritas untuk mengalahkan Setan. Karena orang percaya mengalami kelahiran baru di dalam Kristus, kita memiliki kuasa dan mandat untuk menghadapi Iblis dan kroni-kroninya. Namun kita harus berhati-hati ketika berbicara tentang otoritas ini. Jangan sampai kita lebih mengutamakan pengalaman sebagai dasar kepercayaan dan praktik dalam kehidupan nyata.

Alkitab mencatat bagaimana Yesus memberikan otoritas-Nya (exousian) kepada murid-murid (Mat. 10:1; Mrk. 6:7-13; Luk. 9:1-6), yakni kuasa untuk memerintah. Akan tetapi, otoritas ini tidak bersifat menetap. James

160 . A. Scott Moreau, "Demon," http://www.biblestudytools.com/dictionaries/bakers-evangelicaldictionary/demon.html (diakses 13 Juni 2017).

161. Gregory Brown, "18. How Healthy Churches Resist The Devil (1 Peter 5:6-11)" https://bible.org/seriespage/18-how-healthy-churches-resist-devil-1-peter-56-11 (diakses 15 Juni 2017). 
A. Laine berpendapat otoritas ini juga tidak dapat dikaitkan dengan baptisan Roh Kudus (Kis. 1:4, 8), karena saat Yesus memberikan otoritas, peristiwa pencurahan Roh Kudus belum terjadi.162 Otoritas tersebut adalah otoritas di dalam nama Yesus, nama di atas segala nama. Karena hanya Tuhan yang memiliki otoritas yang bersifat menetap maka Ia berkenan memberikan izin kepada murid-murid-Nya untuk menggunakan nama-Nya sama seperti pemerintah kota atau provinsi yang memberikan otoritas kepada petugas kepolisian, yang ditandai dengan lencana. Ketika orang percaya berserah total kepada Yesus maka kita pun menerima otoritas daripada-Nya.

Orang percaya pada dasarnya memiliki otoritas yang sama dengan apa yang Tuhan berikan kepada rasul-rasul. Alkitab mencatat kebenaran bagaimana orang percaya dinyatakan bersama dengan Kristus dan mendapatkan tempat bersama dengan-Nya di sorga (Ef. 2:6). Akan tetapi, ini bukan berarti orang percaya memiliki otoritas yang sama dengan Kristus karena otoritas yang dimiliki-Nya adalah unik. Filipi 2:10 menyatakan segala yang ada di langit dan yang ada di atas bumi serta di bawah bumi akan berlutut di hadapan Kristus, bukan di hadapan orang percaya. Kita ada di bawah payung otoritas Kristus.163

Contoh nyata dalam hal orang percaya tidaklah memiliki semua otoritas dapat kita lihat dalam kehidupan Paulus. Sebagai rasul, ia mengadakan banyak mukjizat dalam pelayanannya. Ia menyembuhkan orang-orang sakit, tetapi ia tak dapat menyembuhkan penyakitnya sendiri. Jelaslah dari contoh tersebut bahwa meski rasul hebat seperti Paulus memiliki otoritas, ia tidak memiliki semua otoritas. Sebagaimana Paulus, seperti itu juga kita. Walaupun sebagai orang percaya, kita memiliki otoritas, kita tetap perlu berdoa.164

Ketiga, kerendahan hati merupakan kunci dari otoritas orang percaya dalam peperangan rohani. Karena kita tidak memiliki segala otoritas maka

162 James A. Laine, A Biblical View of Demonology http://digitalcommons.liberty.edu/cgi/viewcontent.cgi?article=1054\&context=ccfs_fac_pubs. .1981 . Liberty University. (diakses 13 Juni 2017).

163. Steve Fernandez, Deliverance and Spiritual Warfare: A Biblical Examination of the Deliverance Model of Spiritual Warfare (Vallejo: Exalting Christ Publishing, 2001), 10.

164. “Do We Have All Authority,” http://www.letusreason.org/Latrain16.htm Diakses 5 Juni 2017 
kita perlu rendah hati dengan bersandar sepenuhnya kepada Yesus sebagai pemegang segala otoritas. Berdoa merupakan salah satu bentuk kerendahan hati tersebut sebab dengan berdoa kita mengakui kita memerlukan kekuatan dan tuntunan dari Pribadi yang jauh lebih besar dari kita. Di dalam doalah terletak otoritas orang percaya tersebut. Alkitab mencatat doa orang benar, yang disampaikan dengan penuh keyakinan, sangat besar kuasanya (Yak. 5:16).

Selain itu, orang percaya harus berdoa di dalam nama Tuhan Yesus. Dengan memakai nama Yesus dalam doa kita sama artinya kita menggunakan kuasa-Nya, bukan mengandalkan kekuatan kita. Alkitab mencatat bagaimana Rasul Petrus memerintahkan orang lumpuh berjalan "Demi nama Yesus Kristus" (Kis. 3:6). Dengan demikian ia berbicara kepada orang lumpuh tersebut dengan otoritas Tuhan Yesus, bukan otoritasnya sendiri. Di dalam contoh lain pada Kisah Para Rasul 16:18, Rasul Paulus menghardik seorang hamba perempuan yang mempunyai roh tenung dengan memakai formula yang sama: "Demi nama Tuhan Yesus Kristus." Paulus juga menggunakan otoritas nama Yesus ketika menyatakan penghakiman terhadap jemaat yang bersalah (1Kor. 5:4, 5). Jadi, berdoa di dalam nama Yesus sama dengan berdoa dengan otoritasNya. 165

Namun, orang percaya harus berhati-hati dalam menggunakan nama Yesus sebab berdoa di dalam nama Yesus tidak boleh sembarangan. Kita harus berdoa dengan cara yang konsisten dengan karakter-Nya, yang berarti kehidupan kita haruslah sesuai dengan kehendak-Nya yang kudus. Bahkan di dalam Kolose 3:17 Paulus menandaskan bahwa bukan saja di dalam doa, melainkan setiap aspek kehidupan orang percaya haruslah dilakukan di dalam nama Yesus. Berdoa di dalam nama Yesus juga berarti berdoa "sesuai dengan kehendak-Nya" (1Yoh. 5:14-15). Untuk lebih jelasnya, argumentasi Leon Morris sebagai berikut dapat menjadi bahan kajian: "This does not mean simply using the name as a formula. It means that prayer is to be in accordance with all that the name stands for. It is

165. Wayne Grudem, "Prayer" https://www.biblicaltraining.org/library/prayer-wayne-grudem (diakses 5 Juni 2017). 
prayer proceeding from faith in Christ, prayer that gives expression to a unity with all that Christ stands for, prayer which seeks to set forward Christ himself. And the purpose of it all is the glory of God." 166

Kunci kemenangan dalam peperangan rohani sebenarnya bukanlah terletak pada "mengikat" Setan melainkan ketika orang percaya mengenakan "perlengkapan senjata Allah" (Ef. 6:10, 11). Letak keyakinan orang percaya seharusnya bukanlah pada kemampuan untuk "mengikat Setan" melainkan kepada firman Tuhan dan kekuatan Tuhan di dalam diri orang percaya. Fokus perhatian kita seharusnya adalah kepada kebenaran dan keadilan (Ef. 6:14). Pelayanan kita sepatutnya membagikan Injil dan membangun orang percaya (Ef. 6:15). Kita mempergunakan waktu sebaikbaiknya untuk berdoa (ay. 18). Dengan mengenakan "perlengkapan senjata Allah" serangan Iblis terhadap kita akan menjadi tidak efektif. 167 Ketika perisai iman kita terhadap kuasa dan kasih Allah kuat, mustahil bagi Iblis untuk melancarkan serangan panah apinya.

\section{PENUTUP}

Sebenarnya tidak sepenuhnya keliru pandangan yang menyatakan bahwa Iblis dapat menjatuhkan orang percaya dengan tipu dayanya. Menyatakan hal ini salah sama saja dengan mengingkari kebenaran Alkitab. Akan tetapi bila semua hal yang melenceng dalam kehidupan orang percaya dianggap sebagai kesalahan Iblis maka sama saja dengan mengabaikan tanggung jawab pribadi atas dosa yang dilakukannya. Padahal untuk membereskan dosa, diperlukan pengakuan pribadi. Kita tak dapat menghampiri takhta kemuliaan Allah yang suci tanpa mengakui dosa, baik yang disengaja maupun tidak.

Tentu saja sebagai prajurit Kristus yang hidup di zona perang selama masih ada di dalam dunia ini, setiap orang percaya tetap harus waspada dan berjaga-jaga karena kita menghadapi musuh yang kuat, yakni Iblis dan kuasa kegelapan. Iblis dapat memakai segala bentuk tipu daya untuk

166. Dikutip dalam Grudem, "Prayer" diakses 5 Juni 2017. 2017).

167. "Binding Satan," https://www.growingchristians.org/devotions/binding-satan/ (diakses 29 Mei 
menyesatkan sehingga bila mengandalkan kekuatan sendiri maka kita tak akan dapat memenangkan peperangan tersebut. Setiap orang percaya harus berdiri dengan otoritas Tuhan ketika berhadapan dengan kuasa kegelapan. Doa dan kebenaran firman Tuhan merupakan senjata aktif yang tak boleh ditinggalkan. Dengan doa dan firman Tuhan, orang percaya memiliki kuasa untuk memukul serangan Iblis. Selain itu, sebagaimana digariskan di dalam Efesus 6:10-18, orang percaya tetap harus mengenakan kebenaran, keadilan, dan kerelaan memberitakan Injil di dalam kehidupannya.

Cara terbaik dalam menghadapi peperangan rohani adalah dengan mengakui dosa dan bertobat, berdoa, membaca Alkitab, dan mengerjakan Amanat Agung. Bila memang kita menghadapi kasus yang memerlukan praktik eksorsis, tentu saja kita perlu melakukannya. Akan tetapi, kita tak perlu mengadakan doa pelepasan pribadi setiap hari. Yang perlu dilakukan orang percaya adalah mengaku dosa setiap kali berdoa. Namun, mengaku saja tidak cukup sebab pengakuan dosa itu juga perlu dilengkapi dengan kehidupan yang bertobat. Dengan demikian, strategi yang paling pas yang perlu dikembangkan orang percaya dalam peperangan rohani adalah dengan menjalani hidup sesuai kehendak Tuhan.

\section{BIBLIOGRAFI}

"Binding and Loosing: The Keys to The Kingdom and Exercising Your Spiritual

Authority" https://www.missionariesofprayer.org/2016/05/binding-and-loosing-thekeys-to-the-kingdom-and-exercising-your-spiritual-authority/ (diakses 30 Mei 2017).

"Binding and Loosing: Introduction"

http://www.bindingandloosing.com/ diakses (30 Mei 2017).

"Binding

Satan,"

https://www.growingchristians.org/devotions/binding-satan/ (diakses 29 Mei 2017). 
"Do We Have All Authority,"

http://www.letusreason.org/Latrain16.htm (diakses 5 Juni 2017).

"Matthew 12," https://bible.org/netbible/ (diakses 24 Juni 2017).

"Paula White," https://en.wikipedia.org/wiki/Paula_White (diakses 7 Juni 2017).

"Prayer of Warfare-Binding and Loosing" https://truthinreality.com/2012/08/15/prayer-of-warfare/ (diakses $30 \mathrm{Mei}$ 2017).

"The Prayer of Binding and Loosing and Praying in Tongues" https://victorychristiancentre.co.nz/podcast/prayer-binding-and-loosingand-praying-tongues (diakses 27 Agustus 2017).

Beilby, James K. dan Paul Rhodes Eddy, "Introduction" dalam James K. Beilby dan Paul Rhodes Eddy (eds.). Understanding Spiritual Warfare. Grand Rapids, Michigan: Baker Academic, 2012.

Brown, Gregory. "18. How Healthy Churches Resist The Devil (1 Peter 5:6-11)" https:// bible.org/seriespage/18-how-healthy-churches-resist-devil1-peter-56-11 (diakses 15 Juni 2017).

Buys, PJ (Flip). "A Biblical and Reformed Perspective on Demonology." Christian Library: 1-13. www.christianstudylibrary.org (diakses 20 Juni 2017).

Calvin, John. Commentary on Matthew, Mark, Luke - Volume 2. Michigan: Grand Rapids: n.y. Christian Classical Ethereal Library Commentary Ebook.

Cheddie, Denver. "Are We Supposed to 'Bind and Loose'?" http://www.bibleissues.org/bindloose.html (diakses 30 Mei 2017).

Clarke, Adam. "Matthew 16:19" https://www.studylight.org/commentary/matthew/16-19.html (diakses 31 Mei 2017).

Fernandez, Steve. Deliverance and Spiritual Warfare: A Biblical Examination of the Deliverance Model of Spiritual Warfare. Vallejo: Exalting Christ Publishing, 2001. 
Gill, John. "Matthew 16:19"

http://www.biblestudytools.com/commentaries/gills-exposition-of-thebible/matthew-16-19.html (diakses 31 Mei 2017).

Growing Christian Ministries, "Binding Satan," https://www.growingchristians.org/devotions/binding-satan/ (diakses 29 Mei 2017).

Grudem, Wayne. "Prayer"

https://www.biblicaltraining.org/library/prayer-wayne-grudem (diakses 5 Juni 2017).

Hartwell, George. "Spiritual Warfare Topic: Binding and Loosing" http://www.listening-

prayer.com/spiritual\%20warfare/binding\%20and\%20loosing.html (diakses 30 Mei 2017).

Henry, Matthew. Commentary on the Whole Bible Volume 5. Michigan: Grand Rapids,: n.y. Christian Classical Ethereal Library Commentary Ebook.

Hiers, Richard H. "'Binding' and 'Loosing': The Matthean Authorization," Journal of Biblical Literature (Vol. 104, No. 2) (June 1985) p. 235-250.

Ibbitson, Don. "How to Develop the Gift of Discerning Spirits," https://aandbcounseling.com/develop-gift-of-discerning-spirits/ (diakses 26 Agustus 2017).

King, Paul L. "The Restoration of the Doctrine of Binding and Loosing" Alliance Academic Review (1997): n.p., http://www.kneillfoster.com/aar/1997/AAR1997-5.php (diakses 6 Juni 2017).

King, Paul L. "John McMillan and the Authority of the Believer," http://pneumareview.com/john-macmillan-authority-of-the-believer. (diakses 26 Agustus 2017)

Laine, James A. A Biblical View of Demonology http://digitalcommons.liberty.edu/cgi/viewcontent.cgi?article $=1054 \&$ contex

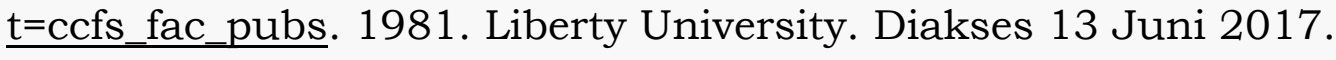


Marshall, Ruth. "Destroying Arguments and Captivating Thoughts: Spiritual Warfare Prayer as Global Praxis" Journal of Religious and Political Practice (Vol. 2: No. 1) p. 92-113.

Masters, Peter. "Cessationism-Proving Charismatic Gifts have Ceased" http://www.metropolitantabernacle.org/Christian-Article/CessationismProving-Charismatic-Gifts-have-Ceased-Sword-and-Trowel-Magazine\# (diakses 26 Agustus 2017).

Moreau,

A.

Scott.

"Demon,"

http:/ / www.biblestudytools.com/dictionaries/bakers-evangelicaldictionary/demon.html (diakses 13 Juni 2017).

Nunnally, W.E. "Binding and Loosing: A Biblical Perspective on a Popular Modern

Practice" http://enrichmentjournal.ag.org/200901/200901_112_theo_enrichment.cf $\underline{\mathrm{m}}$ (diakses 29 Mei 2017).

Schaff (ed.), Philip. NPNF1-08. St. Augustine: Exposition on the Book of Psalms. Michigan: Grand Rapids, n.y. Christian Classical Ethereal Library Commentary Ebook.

Stitzinger, James. "Spiritual Gifts: Definitions and Kinds" TMSJ (14/2) (Fall 2003) (p. 143-176) 172-175.

Wallace, Daniel B. "Two Views on the 'Sign Gifts': Continuity Vs. Discontinuity" https://bible.org/article/two-views-sign-gifts-continuity-vsdiscontinuity. (diakses 26 Agustus 2017).

White, Paula. "Prayer: Binding The Strongman," https://paulawhite.org/binding-the-strongman-2016/ (diakses 30 Mei 2017).

Zumpano, Bern. Spiritual Warfare Prayers. Miami, Florida: Harbor Light, 1999.

Zumpano, Bern. "The Prayer of Binding and Loosing" http://www.cryoutreach.com/prayer-of-binding-and-loosing.html (diakses 30 Mei dan 27 Agustus 2017).

PENULIS 
Murni Hermawaty Sitanggang, S.Th. (lulus tahun 2004 dari Sekolah Tinggi Alkitab Jember), M.Th. (lulus tahun 2008 dari Seminari Alkitab Asia Tenggara Malang).

Afiliasi: Dosen Pendidikan Agama Kristen di Unit Pelaksana Teknis Bidang Studi Mata Kuliah Umum (UPT-BSMKU) di Universitas Jember dan Dosen Teologi dan Biblika di Sekolah Tinggi Alkitab Jember; berjemaat dan melayani di GPdI Ekklesia Jember. 